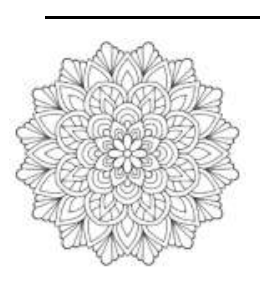

AL HIKMAH: INDONESIAN JOURNAL OF EARLY CHILDHOOD ISLAMIC EDUCATION

ISSN (P): 2550-2200, ISSN (E): 2550-1100,

VOL. 5 (2), 2021, PP. 79 - 89

http://journal.iaialhikmahtuban.ac.id/index.php/ijecie

\title{
DAMPAK IMPLEMENTASI PEMBELAJARAN DARING TERHADAP KARAKTER ANAK DI MASA PANDEMI COVID-19
}

\author{
Alfi Rohmatul Azizah ${ }^{1}$, Ahmad Samawi ${ }^{2}$, Nur Anisa ${ }^{3}$ \\ ${ }^{123}$ Program Studi Pendidikan Guru Pendidikan Anak Usia Dini, Universitas Negeri Malang \\ alfi.rohmatul.1701536@students.um.ac.id,ahmad.samawi.fip@um.ac.id,nur.anisa.fip@um.ac.id
}

\begin{abstract}
Abstrak
Pandemi Covid-19 menyebabkan transformasi sistem pembelajaran dalam dunia telah berubah dengan cepat. Pembelajaran dilakukan melalui jaringan memiliki dampak terhadap terbentuknya karakter anak. Penelitian ini bertujuan untuk mendeskripsikan dampak dari implementasi pembelajaran daring terhadap karakter anak yang terbentuk selama pembelajaran daring menggunakan google classroom dan zoom meeting. Penelitian ini menggunakan pendekatan kualitatif dengan desain studi kasus. Teknik pengumpulan data melalui observasi, wawancara, kuisioner, dan dokumentasi. Hasil dari penelitian ini dapat diketahui bahwa munculnya dampak positif dan negatif pada karakter anak ketika pembelajaran daring melalui google classroom dan zoom meeting. Dampak positif dari implementasi pembelajaran daring di masa pandemi Covid-19 ditunjukkan dengan kemahiran anak dalam menggunakan teknologi pembelajaran dan munculnya karakter-karakter tertentu seperti disiplin, tanggungjawab, religius, nasionalisme, berani, sabar dan mandiri. Disisi lain, implementasi pembelajaran daring menyebabkan menurunnya kemampuan bersosialisasi anak.
\end{abstract}

Kata Kunci: Pembembelajaran daring, karakter anak usia dini, pandemi covid-19
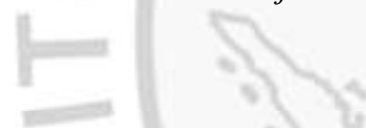

\section{Abstract}

The COVID-19 pandemic was caused the transformation of the learning system in the world to change rapidly. Learning through the network effects creating childhood's character. The study aims to describe the impact of the implementation of online learning on the character of children generated during the online study using the google classroom and zoom cloud meeting. The study used a qualitative approach with case studies in data collection by observation, interview, questionnaire, and documentary. As a result of this study, it may be noted that there has been a positive and negative effect on the character of children when online study through google classroom and zoom cloud meeting. The positive effect of the implementation of online learning during the covid-19 pandemic is demonstrated with child competence in the use of learning technology and the emergence of certain characteristics such as responsibility, discipline, religion, nationalism, courage, patience, and selfsufficiency. On the other hand, the implementation of online learning causes a drop in child sociability.

Keywords: Online Learning, Childhood's Character, COVID-19 pandemic. 


\section{PENDAHULUAN}

Baru-baru ini dunia dikejutkan dengan penyakit yang berasal dari Kota Wuhan, China yang merupakan penyakit jenis virus baru. Penyakit tersebut bernama Coronavirus Desease atau Covid-19 (Pramana, 2020). Virus Covid-19 masuk ke Indonesia pada awal bulan Maret 2020 dan berhasil melumpuhkan seluruh aspek sektor bidang. Hal tersebut mendorong pemerintah untuk mengeluarkan beberapa kebijakan sebagai alternatif pemutus rantai penyebaran Covid-19 dengan menekankan masyarakat untuk menjaga jarak fisik dan sosial dalam setiap aktivitasnya (Yoshikawa dkk, 2020 dan Pramana, 2020). Pengeluaran kebijakan dari pemerintah tersebut menyebabkan sektor bidang mengalami kendala karena belum memiliki kesiapan untuk menjalankannya termasuk dalam dunia pendidikan. Pemerintah pusat dan daerah menegaskan untuk meliburkan sekolah guna mengurangi aktivitas fisik dan sosial (Samsudin, 2020). Pemerintah dan lembaga pendidikan terkait kemudian mengatur jalannya sistem pendidikan sebagai bentuk pemberian layanan pendidikan kepada peserta didik dalam Surat Edaran No. 15 Tahun 2020 tentang pelaksanaan Pembelajaran dalam Masa Darurat Coronavirus Desease (Covid-19). Pedoman tersebut mengatur jalannya sistem pembelajaran jarak jauh menggunakan pembelajaran dalam jaringan (daring) yang dilaksanakan dari rumah dengan aktivitas dan tugas pembelajaran dapat divariasikan dengan minat dan kondisi masing-masing, termasuk dalam hal kesenjangan akses/fasilitas belajar di rumah (SE Kemendikbud No. 15 Tahun 2020). Peraturan tersebut diberlakukan untuk semua jenjang pendidikan yang didalamnya tersaut juga untuk pendidikan anak usia dini.

Pendidikan anak usia dini pada umumnya melakukan kegiatan pembelajaran dengan tatap muka secara langsung, mengingat anak usia dini masih membutuhkan bimbingan dan perhatian guru dalam proses pembelajarannya Adanya transisi sistem pembelajaran pada anak usia dini, kegiatan pembelajaran tatap muka tergantikan menjadi pembelajaran menggunakan media teknologi komunikasi berbasis jaringan (online). Hal tersebut menyebabkan aspek perkembangan dan karakter anak menurun (Wulandari \& Purwanta, 2020). Aspek perkembangan dan karakter anak biasanya terbentuk melalui pembiasaan dengan adanya interaksi secara langsung antara guru dan anak dalam proses pembelajaran. Interaksi tersebut menghasilkan perilaku yang diwujudkan dengan nilai-nilai positif yang diulang-ulang hingga akhirnya membentuk sebuah karakter melalui pembiasaan dan peneladanan dalam kegiatan pembelajaran (Rihlah, 2020). Menurunnya nilai-nilai karakter pada anak usia dini menuntut adanya kreativitas guru dalam sistem pembelajaran berbasis jaringan dengan memanfaatkan media teknologi komunikasi seperti zoom meeting, google classroom, whatssapp group, dan lain sebagainya sebagai media sinkronisasi sistem pembelajaran. 
Sinkronisasi kegiatan pembelajaran yang dilakukan melalui google classroom dan zoom meeting dilakukan oleh salah satu TK di Kota Malang yaitu Taman Kanak-kanak Children Center Brawijaya Smart School (BSS) Universitas Brawijaya. Penggunaan kedua aplikasi itu sangat membantu pembelajaran daring di TK tersebut. Kegiatan pembelajaran yang dilaksanakan pada kelompok B di TK Children Center BSS UB memunculkan beberapa karakter seperti karakter religius, karakter disiplin, karakter tanggung jawab dan karakter nasionalis. TK tersebut menggunakan media teknologi google classroom dan zoom meeting sebagai media pembelajaran berbasis jaringan dan menggunakan whatssapp group sebagai media pemberian informasi kepada wali murid terkait informasi mengenai pembelajaran dan sekolah.

Penelitian tentang dampak dari pembelajaran daring terhadap pembentukan karakter pada anak di TK Children Center BSS UB pada kelompok B. Penulis ingin mengetahui sistem pembelajaran daring yang dilakukan secara mendalam di TK tersebut dimana implementasi pembelajaran daring yang dilakukan mampu memunculkan dan menonjolkan nilai-nilai karakter pada anak usia 5-6 tahun. Penelitian ini dilakukan pada kelompok B di Taman Kanak-kanak Children Center Brawijaya Smart School (BSS) Universitas Brawijaya, Kota Malang. Tujuan dari penelitian ini adalah untuk mendeskripsikkan implementasi pembelajaran daring, kendala implementasi pembelajaran daring dan upaya mengatasinya, upaya pembentukan karakter dalam pembelajaran daring, dampak implementasi pembelajaran daring terhadap karakter anak usia dini masa pandemi Covid-19 khususnya di TK Children Center BSS UB.

\section{METODE}

Penelitian ini menggunakan pendekatan kualitatif dengan desain penelitian studi kasus. Penelitian kualitatif dengan metode studi kasus dipilih dikarenakan penelitian ini memiliki kekhususan dalam tujuan dan sifat objek yang diteliti. Menurut Yin (2009) penelitian kualitatif dengan desain studi kasus bersifat kontemporer, masih terkait dengan masa kini, baik yang sedang terjadi maupun telah selesai namun masih memiliki dampak. Penelitian ini sesuai dengan permasalahan yang sedang terjadi dengan konteks penelitian yang diambil oleh peneliti. Peneliti diharuskan untuk terjun ke lapangan untuk menggali informasi sesuai dengan fakta dan situasi yang terjadi terkait dampak dari implementasi pembelajaran daring terhadap karakter anak usia dini di masa Pandemi Covid-19. 
Alfi Rohmatul Azizah, dkk (Dampak Implementasi Pembelajaran Daring)

Penelitian ini dilaksanakan di TK Children Center Brawijaya Smart School Universitas

Brawijaya (CC BSS UB) Kota Malang pada kelompok B. Lembaga tersebut menggunakan media teknologi komunikasi google classroom dan zoom meeting dalam mengimplementasikan pembelajaran daring yang sesuai dengan konteks penelitian. Sumber data dari penelitian ini yaitu data primer dan data sekunder. Data primer diperoleh secara langsung dari guru kelas dan orang tua melalui wawancara dan mengiri kuisioner pada google form yang telah disediakan. Data sekunder diperoleh dari dokumen, buku dan lainnya terkait dengan topik penelitian. Adapun data sekunder yang dibutuhkan dalam penelitian ini yaitu jumlah anak dan wali murid, foto-foto, dokumen yang dapat berupa catatan pribadi, buku notulen rapat, bagan dan lain sebagainya dan hal yang berkaitan dengan TK CC BSS Universitas Brawijaya Kota Malang. Data sekunder ini digunakan untuk melengkapi dan memperkuat informasi yang telah dikumpulkan melalui wawancara dari narasumber.

Teknik pengumpulan data dalam penelitian ini menggunakan observasi, wawancara, kuisioner dan dokumentasi. Instrumen yang digunakan yaitu lembar observasi, pedoman wawancara, pedoman dokumentasi dan lembar kuisioner. Lembar observasi digunakan untuk mengamati pembelajaran daring yang dilakukan. Pedoman wawancara dan lembar kuisioner digunakan untuk memperoleh informasi terkait konteks penelitian yang ditujukan kepada guru kelas dan wali murid, dan pedoman dokumentasi digunakan untuk mencari dan menggali dokumen sebagai pelengkap hasil observasi dan wawancara.

Analisis data yang digunakan menggunakan analisis data model Miles dan Huberman yang membagi menjadi tiga tahap yaitu tahap kondensasi data, tahap penyajian data, dan tahap penarikan kesimpulan. Untuk memperoleh penelitian yang kredibel dan bermakna, peneliti melakukan recheck data dengan teknik triangulasi sumber data dengan membandingkan hasil wawancara dan kuisioner antar sumber data.

\section{HASIL DAN PEMBAHASAN}

Implementasi Pembelajaran Daring

Pembelajaran dalam jaringan (daring) yang dilaksanakan di TK Children Center BSS UB menggunakan dua media teknologi yaitu google classroom dan zoom meeting. Kedua media tersebut digunakan sebagai sarana untuk pelaksanaan pembelajaran daring. Pembelajaran daring dilaksanakan sebagai salah satu alternatif pelaksanaan pembelajaran di masa Pandemi Covid-19. Taman Kanak-kanak Children Center BSS UB melaksanakan pembelajaran daring menggunakan kedua media tersebut sejak diumumkannya pembelajaran 
Alfi Rohmatul Azizah, dkk (Dampak Implementasi Pembelajaran Daring)

yang harus dilaksanakan dari rumah sesuai dengan petunjuk dalam Surat Edaran Kementerian dan Kebudayaan No. 15 Tahun 2020 tentang Pelaksanaan Pembelajaran dari Rumah Selama Masa Darurat Pandemi Covid-19. Dalam surat edaran tersebut, pelaksanaan pembelajaran daring meliputi: perencanaan pembelajaran daring, pelaksanaan pembelajaran daring, sesudah pembelajaran daring dan evaluasi pembelajaran daring.

Perencanaan pembelajaran ditafsirkan oleh Andini \& Widayanti (2020) meliputi pengukuran kebutuhan anak, sistem pendukung, desain pembelajaran, materi pembelajaran, platform yang tepat, dan evaluasi hasil belajar. Kesiapan dari guru dalam pelaksanaan pembelajaran daring juga merupakan bentuk dari perencanaan pembelajaran daring. Seperti yang dijelaskan oleh Ayuni, dkk (2020) bahwa keberhasilan anak dalam melaksanakan pembelajaran daring tergantung pada kesiapan yang dilakukan guru dalam perencanaan pembelajaran daring. Guru di TK Children Center BSS UB melakukan perencanaan dan persiapan sebelum melakukan pembelajaran daring yang meliputi rencana pelaksanaan pembelajaran harian (RPPH), media yang digunakan dalam pembelajaran daring baik pembelajaran yang dilaksanakan melalui Zoom Meeting maupun Google Classroom, dan juga akses jaringan internet. Guru juga mengingatkan kembali kepada orang tua terkait pembelajaran yang akan dilakukan sejak satu jam sebelum pelaksanaan pembelajaran daring.

Pembelajaran daring di TK Children Center BSS UB dilaksanakan setiap hari senin rabu pukul 08.00 - 09.00 am via zoom meeting dan tugas daring via google classroom diupload setiap hari jum'at. Tugas daring merupakan kegiatan pembelajaran yang dilaksanakan di rumah dan dikerjakan pada hari tertentu sesuai pilihan anak dan orang tua dengan jadwal pengumpulan tugad daring setiap hari jum'at. Kegiatan pembelajaran yang dilaksanakan via zoom meeting yakni kegiatan pembelajaran keaksaraan. Kegiatan pembelajaran via zoom dibuka dengan salam/kegiatan pembuka, dan dilanjutkan dengan absensi, penyampaian materi, dan kegiatan inti pembelajaran daring. Pembelajaran tersebut ditutup dengan salam dan pesanpesan untuk selalu menjaga kesehatan serta memakai masker ketika keluar rumah. Sesudah pembelajaran, guru mengingatkan kembali pada anak untuk mengerjakan tugas daring pada google classroom dan mengumpulkan tugas tepat waktu.

Penilaian dan evaluasi pembelajaran daring yang dilakukan di TK Children Center BSS UB disesuaikan dengan prosedur penilaian selama pandemi Covid-19 yang dikeluarkan oleh Kemendikbud Tahun 2020. Guru melakukan penilaian melalui google classroom berupa video anak mengumpulkan tugas daring yang sudah diupload. Sedangkan, penilaian pembelajaran 
Alfi Rohmatul Azizah, dkk (Dampak Implementasi Pembelajaran Daring)

daring melalui zoom meeting dilakukan ketika anak menunjukkan hasil pekerjaannya pada layar kamera yang kemudian discreen shoot oleh guru. Guru juga meminta anak untuk mengumpulkan tugas daring via zoom ketika orang tua datang ke sekolah untuk mengambil tugas daring pada minggu selanjutnya.

\section{Kendala Implementasi Pembelajaran Daring Upaya Mengatasinya}

Kendala yang ditemui selama pembelajaran daring di TK Children center BSS UB diantaranya yaitu akses internet dan ruang penyimpanan online, penggunaan teknologi dalam pembelajaran daring dan kebosanan anak selama kegiatan pembelajaran daring. Akses jaringan internet merupakan kunci utama dalam pelaksanaan pembelajaran dalam jaringan (daring). Seperti yang telah disampaikan oleh Kemendikbud (2020) bahwa keterbatasan jaringan internet akan membuat pembelajaran daring yang dilaksanakan tidak efektif untuk dijalankan. Permasalahan jaringan internet di TK BSS yang sering naik turun ketika pembelajaran daring membuat kegiatan pembelajaran sedikit tertunda. Oleh karena itu, pihak sekolah memberikan fasilitas router WIFI sehingga jaringan internet bisa merata keseluruh lingkungan sekolah. Selain itu, ruang penyimpanan yang sering penuh dikarenakan data yang tersimpan pada google drive ketika pembelajaran via google classroom kemudian diatasi oleh guru. Orang tua hanya diminta untuk mengshare link tugas anak. Penguploadan tugas yang terlalu sering pada laman google classroom membuat cara tersebut lebih efektif dan signifikan untuk dilakukan.

Penggunaan google classroom dan zoom meeting sebagai media pembelajaran tentunya menjadi hal yang awam bagi orang tua. Siahaan (2020) mengatakan bahwa keberhasilan anak dalam pembelajaran daring juga ditentukan oleh andil orang tua dalam mendampingi anak selama kegiatan pembelajaran daring. Hal tersebut menuntut orang tua untuk dapat beradaptasi dalam penggunaan teknologi pembelajaran yang terus berkembang. Dalam mengatasi permasalahan tersebut, pihak sekolah memberikan sosialisasi sebelum pembelajaran daring dilakukan. Selain itu, guru juga dibekali dengan pelatihan IT agar pembelajaran daring yang dilakukan berjalan dengan lancar.

Penggunaan teknologi dalam pembelajaran daring secara terus menerus ternyata membuat kejenuhan dan kebosanan pada anak. Anak harus duduk diam didepan layar smarhphone/leptop dengan memperhatikan penjelasan guru untuk mengikuti kegiatan pembelajaran daring. Hal tersebut dijelaskan oleh Rohayani (2020) bahwa anak yang hanya berdiam di rumah dan melakukan kegiatan yang cenderung sama akan menimbulkan kebosanan pada anak, mengingat anak masih belum bisa mengendalikan emosinya. Terlebih 
Alfi Rohmatul Azizah, dkk (Dampak Implementasi Pembelajaran Daring)

lagi, anak hanya memiliki waktu konsentrasi selama kurang lebih 20 menit. Keadaan tersebut benar-benat menuntut guru untuk dapat menciptakan pembelajaran yang interaktif, kreatif dan inovatif. Selain itu, peran orang tua dalam memberikan motivasi dan semangat kepada anak agar anak memiliki antusiasme mengikuti pembelajaran daring. TK Children Center BSS UB menyisipkan ice breaking dan juga reward untuk anak agar anak semangat dalam mengikuti kegiatan pembelajaran hingga selesai.

\section{Upaya Pembentukan Karakter dalam Pembelajaran Daring}

Karakter merupakan nilai-nilai positif yang menjadi cerminan berperilaku dalam kehidupan sehari-hari. Menurut Kamilah (2019) karakter merupakan ciri khas yang dimiliki seseorang yang membedakan satu orang dengan yang lainnya melalui tingkah laku, tabiat, akhlak dan kepribadiannya. Berdasarkan teori dari Lickona (2013) karakter yang baik terbentuk melalui pengetahuan moral, perasaan moral dan diaplikasikan dalam bentuk tindakan. Pendidikan sebagai wadah untuk pembentukan karakter anak usia dini. Pada masa Pandemi Covid-19, penanaman karakter anak harus tetap diberikan. TK Children Center BSS UB tetap menyisipkan nilai-nilai moral dan karakter dalam kegiatan pembelajaran yang dilakukan melalui dua media aplikasi google classroom dan zoom meeting. Karakter anak yang dibentuk di lembaga tersebut menggunakan metode pembiasaan dan penguatan. Metode pembiasaan dilakukan melalui kegiatan pembelajaran pada google classroom dan zoom meeting. Guru juga melakukan penguatan karakter pada kegiatan zoom meeting. Karakter yang paling dominan muncul di kelompok B di TK Children Center BSS UB yakni karakter religius, karakter disiplin, karakter tanggung jawab dan karakter nasionalis.

Metode pembiasaan dan penguatan melalui zoom meeting pada pembelajaran daring di kelompok B juga memunculkan karakter lain, seperti karakter sabar, berani dan mandiri. Karakter sabar muncul ketika guru selalu meminta anak untuk menunggu giliran saat pembelajaran daring. Kebiasaan menunggu giliran tersebut membuat anak sabar menunggu tanpa membuat kegaduhan dan kebisingan. Karakter berani muncul pada anak ketika anak yang sudah selesai mengerjakan tugas mau menunjukkan tugas ke layar smarthphone/leptop tanpa malu. Karakter mandiri muncul ketika anak mengerjakan tugas yang diberikan via zoom meeting secara mandiri tanpa bantuan dari orang tua. Hal tersebut membuktikn bahwa karakter pada anak usia kelompok B dapat terbentuk selama kegiatan pembelajaran daring melalui metode pembiasaan dan penguatan.

\section{Dampak Implementasi Pembelajaran Daring Terhadap Karakter Anak Usia Dini Di Masa Pandemi Covid-19 di Masa Pandemi Covid-19}


Alfi Rohmatul Azizah, dkk (Dampak Implementasi Pembelajaran Daring)

Pembelajaran daring memberikan dampak dalam pelaksanaannya membentuk karakter anak usia dini. Karakter anak terbentuk melalui kebiasaan yang ditanamkan oleh guru dalam aktivitas kegiatan pembelajaran. Nilai-nilai karakter yang ditanamkan pada anak usia dini perlu memperhatikan tahapan perkembangan moral anak (Suyanto, 2012). Oleh karena itu, pendidikan karakter pada anak usia dini merupakan hal fundamental yang sangat penting bagi kelangsungan perkembangan anak dimasa depan. Membentuk karakter pada anak usia dini bukanlah hal remeh, sehingga diperlukan pembiasaan, peneladanan dan penguatan dalam setiap materi yang diajarkan pada anak.

Pembelajaran daring yang dilaksanakan di taman kanak-kanak tentunya memberikan dampak positif dan negatif bagi perkembangan karakter anak. Pembelajaran di TK Children Center BSS UB menggunakan dua media berbasis jaringan internet yaitu google classroom dan zoom meeting. Guru memberikan tugas daring yang dikerjakan di rumah melalui google classroom dan juga melakukan pembelajaran melalui zoom. Guru melakukan sinkronisasi kegiatan pembelajaran melalui zoom dan google classroom sehingga dengan demikian dapat memberikan pembiasaan nilai karakter sekaligus penguatan karakter pada anak. Kegiatan yang dilakukan guru memberikan dampak positif pada perkembangan karakter anak. Berdasarkan hasil observasi dan wawancara, anak memiliki kecenderungan memunculkan karakter religius, disiplin, tangggung jawab dan nasionalis. Selain itu, anak juga memiliki sikap berani, sabar dan mandiri.

Religius merupakan nilai kebajikan yang berlandaskan agama sebagai pedoman dalam bersikap dan berperilaku (Ahsanulkhaq, 2019). Karakter religius ditanamkan melalui pembiasaan, penguatan dan peneladanan dalam kehidupan sehari-hari. Nilai-nilai religius ditanamkan di sekolah melalui kegiatan sederhana seperti berdoa sebelum dan sesudah pembelajaran, mengucap dan membalas salam guru, dan melafazkan surat pendek serta doa sehari-hari. TK Children Center BSS UB membentuk karakter religius pada anak dalam kegiatan pembelajaran daring melalui zoom meeting dengan metode pembiasaan dan penguatan.

Pembelajaran daring membentuk karakter disiplin anak melalui kebiasaan yang dibentuk pada anak dalam menyelesaikan tugas yang diberikan guru, mengikuti kegiatan pembelajaran daring secara rutin, dan memakai seragam ketika pembelajaran daring. Disiplin merupakan perilaku tertib dan patuh terhadap aturan. Anak usia dini yang dibiasakan untuk mengikuti aturan sejak dini akan membentuk kedisiplinan anak di masa depan. Selain itu, 
Alfi Rohmatul Azizah, dkk (Dampak Implementasi Pembelajaran Daring)

pembiasaan yang dilakukan selama pandemi Covid-19 juga terbentuk pada anak melalui rutinitas mencuci tangan sebelum dan setelah melakukan kegiatan serta selalu memakai masker ketika hendak keluar rumah. Anak menjadi spontan melakukan kegiatan tersebut tanpa harus diberi tahu oleh orang tua mereka.

Karakter nasionalisme disisipkan oleh guru dalam kegiatan pembelajaran daring tepat sebelum kegiatan inti pembelajaran dilakukan. Kegiatan yang mencerminkan karakter tersebut yang diterapkan dalam pembelajaran daring merupakan kegiatan yang cukup mudah dilakukan. Hal tersebut bertujuan agar karakter nasionalisme tetap dibentuk pada anak selama kegiatan pembelajaran daring. Nasionalisme dalam bentuk sederhana seperti menyanyikan lagu kebangsaan dan mengenal lambang negara. Guru menyisipkan dan membentuk karakter nasionalisme melalui zoom meeting dan juga diaplikasikan melalui google classroom yang diawasi oleh orang tua. Karakter tersebut terlihat ketika pembelajaran daring melalui zoom meeting saat anak menyanyikan lagu kebangsaan secara bersama-sama dan mandiri dengan sikap tegak berdiri dengan suara lantang.

Karakter tanggung jawab diaplikasikan dalam bentuk kegiatan rutinitas anak mengumpulkan tugas yang diberikan guru melalui google classroom. Anak yang mampu menyelesaikan tugas sampai selesai dan merapikan media yang digunakan setelah kegiatan pembelajaran daring telah menunjukkan berperilaku bertanggung jawab. Berdasarkan data hasil wawancara dan kuisioner penelitian, anak memiliki peningkatan dalam bertanggung jawab dengan rentang 57\%-78\%.

\section{PENUTUP}

\section{Simpulan}

Kegiatan pembelajaran dalam jaringan (daring) dilaksanakan di Taman Kanak-kanak Brawijaya Smart School (BSS) Universitas Brawijaya dengan memanfaatkan media teknologi komunikasi google classroom dan zoom cloud meeting. Pemanfaatan kedua media tersebut sangat membantu kegiatan pembelajaran daring yang diterapkan. Kegiatan pembelajaran via google classroom diupload oleh guru setiap hari jum'at dengan memberikan tugas daring yang dikerjakan anak di rumah, sedangkan kegiatan pembelajaran via zoom meeting dilaksanakan setiap senin - rabu. Penilaian hasil karya anak dilakukan melalui hasi belajar yang dikirimkan pada laman google classroom dan hasil capture ketika pembelajaran via zoom meeting. 
Alfi Rohmatul Azizah, dkk (Dampak Implementasi Pembelajaran Daring)

Dalam penerapan kegiatan pembelajaran daring, TK Children Center BSS UB menghadapi beberapa kendala yaitu diantaranya: terbatasnya akses jaringan internet dan ruang penyimpanan online, penggunaan teknologi dalam pembelajaran daring, dan kebosanan anak ketika pembelajaran daring dilakukan. Untuk mengatasi permasalahan tersebut, pihak sekolah memberikan fasilitas tambahan agar kegiatan pembelajaran dapat berjalan dengan lancar. Guru juga memberikan arahan agar orang tua mengshare link hasil tugas daring anak untuk menghemat ruang penyimpanan online. Pihak sekolah juga melakukan pelatihan kepada guru dan orang tua melalui sosialisasi tentang pelaksanaan pembelajaran daring dan penggunaan teknologi dalam pembelajaran daring. Guru melakukan inovasi kegiatan pembelajaran dengan tetap menyisipkan nilai karakter agar pembelajaran yang dilakukan tetap menarik.

Pembentukan karakter anak dilakukan di TK Children Center BSS UB melalui pembiasaan dan penguatan dalam kegiatan pembelajaran daring. Anak dibiasakan untuk berperilaku sabar, mandiri, tanggungjawab, bersikap santun, disiplin dan bersikap religi dalam kegiatan pembelajaran daring. Pembiasaan karakter dalam kegiatan pembelajaran daring dilakukan melalui zoom meeting dan google classroom, sedangkan penguatan karakter dilakukan melalui zoom meeting.

Penerapan kegiatan pembelajaran daring di TK Children center BSS UB memberikan dampak positif dan negatif pada karakter anak. Dampak positif yang muncul yaitu kemahiran anak dalam menggunakan teknologi dan terbentuknya karakter tertentu seperti disiplin, tanggungjawab, religius, nasionalisme, mandiri, sabar, dan berani. Disisi lain, menurunnya kemampuan bersosialisasi anak menjadi dampak negatif dari implementasi pembelajaran daring yang diterapkan.

\section{DAFTAR PUSTAKA}

Andini, Y. T \& Widayanti, M. D. 2020. Pelaksanaan Pembelajaran Daring pada Masa Pandemi Covid-19 di Tk Bias Yogyakarta. Tarbiyatuna: Kajian Pendidikan Islam, 4(2), 207-216 http://ejournal.iaiibrahimy.ac.id/index.php/tarbiyatuna/article/view/424

Ahsanulkhaq, M. 2019.Membentuk Karakter Religius Anak Melalui Metode Pembiasaan. Jurnal Prakarsa Paedagogia, 2 (1), 21-33. http://jurnal.umk.ac.id/index.php/pendas/index

Ayuni, D., Marini, T., Fauziddin, M., \& Pahrul, Y. 2020. Kesiapan Guru TK Menghadapi Pembelajaran Daring Masa Pandemi Covid-19. Jurnal Obsesi: Jurnal Pendidikan Anak Usia Dini, 5(1), 414-421. https://www.obsesi.or.id/index.php/obsesi/article/view/579

Kamilah, S. 2019. Mengembangkan Karakter Anak Usia Dini Usia 5-6 Tahun Melalui Media Animasi Kartun Di Tk Setia Kawan Panjang Bandar Lampung. SKRIPSI 
Alfi Rohmatul Azizah, dkk (Dampak Implementasi Pembelajaran Daring)

Kementerian Pendidika dan Kebudayaan Republik Indonesia. 2020. Surat Edaran No. 15

Tahun 2020 tentang Pedoman Penyelenggaraan Belajar dari Rumah Dalam Masa Darurat Coronavirus Desease (COVID-19)

Kementerian Pendidikan dan Kebudayaan Republik Indonesia. 2020. Penilaian Perkembanngan Anak Selama Belajar Dari Rumah.

Lickona, T. 2013. Character Matters: Persoalan Karakter. Jakarta: Bumi Aksara

Pramana, C. 2020. Pembelajaran Pendidikan Anak Usia Dini (PAUD) Di masa Pandemi Covid19. Indonesia Journal of Early Childhood: Jurnal Dunia Anak Usia Dini, 2(2), 115-123 http://jurnal.unw.ac.id:1254/index.php/IJEC/article/view/557

Rihlah, J., kamilah, U., \& Shari, D. 2020. Gambaran Pendidikan Karakter Anak Usia Dini di Masa Pandemi Covid-19. PAUD Lectura: Jurnal Pendidikan Anak Usia Dini, 4(01), 5161. http://journal.unilak.ac.id/index.php/paud-lectura/article/view/4878

Rohayani, F. 2020. Menjawab Problematika Yang Dihadapi Anak Usia Dini di Masa. Qawwam: Journal For Gender Mainstreaming, 14(1), 29-50. https://doi.org/10.20414/Qawwam.v14i1.2310

Samsudin, U. 2020. Pendidikan Kritis Di Era Pandemi Covid-19 Dan Media Sosial. Tarbawi, 3(2), 150-168 https://stai-binamadani.e-journal.id/Tarbawi/article/view/184

Siahaan, M. 2020. Dampak Pandemi Covid-19 Terhadap Dunia Pendidikan. Jurnal Kajian Ilmiah (JKI), 1, 1 - 3. http://ejurnal.ubharajaya.ac.id/index.php/JKI

Suyanto, S. 2012. Pendidikan Karakter Untuk Anak Usia Dini. Jurnal Pendidikan Anak, 1(1). https://journal.uny.ac.id/index.php/jpa/article/view/2898

Yin, R. K. 2009. Case Study Research: Design and Method. California, Sage Publications, Inc.

Yoshikawa, H., Wuermli, A. J., Britto, P. R., Dreyer, B., Leckman, J. F., Lye, S. J.,... \& Stein, A. 2020. Effects Of The Global Covid-19 Pandemic On Early Childhood Development: Short-And Long-Term Risk And Mitigating Program And Pilivy Anctions. The Journal Of Pediatrics. https://www.jpeds.com/article/S0022-3476(20)30606-5/abstract

Wulandari, H., \& Purwanta, E. 2020. Pencapaian Perkembangan Anak Usia Dini Di Taman Kanak-Kanak Selama Pembelajaran Daring Di Masa Pandemi Covid-19. Jurnal Obsesi: Jurnal Pendidikan Anak Usia Dini, 5(1), 452-462. https://obsesi.or.id/index.php/obsesi/article/view/626 